myocardial infarction, 40 patients with ischaemic cardiac disease, and 24 patients with other conditions.

S.H.B.D. values were found to be elevated, often markedly, at some stage in every patient with recent myocardial infarction. Smaller elevations were found in some patients with myocardial ischaemia, pulmonary infarction, pneumonia, or bronchitis.

An S.H.B.D. value of 140 units/1. has been chosen as the most appropriate value for differentiating between recent myocardial infarction and other conditions, including myocardial ischaemia. In 9 out of 10 patients with myocardial infarction S.H.B.D. results are above this level at some stage within three days of the acute episode, and the elevation persists for 10 days in four patients out of five. This is of particular diagnostic value when the patient is admitted some days after the event.

The diagnostic efficiency of S.H.B.D. determination is greater than that of S.G.O.T. determination, especially in the period 3 to 10 days after the acute episode, and compares favourably with that of the E.C.G.

S.H.B.D. values after myocardial infarction appear to be of little prognostic value.
We should like to thank the various physicians who have allowed us to study patients under their care. We are grateful to Dr. M. F. Oliver for his helpful criticism during this study, and to Dr. R. A. Cumming for the samples of normal blood.

REFERENCES

Baron, D. N., Alexander, C. P., Bell, J. L., and Oakley, C. M. (1958), Quart. F. Med., 27, 533

Elliott, B. A., Jepson, E. M., and Wilkinson, J. H. (1962). Clin. Sci., 23,305 . and Wilkinson, J. H. (1961). Lancet, 1, 698

Karmen (1963). Clin. Sci., 24, 343.

A. (1955). F. clin. Invest. $34,131$.

Konttinen, A., and Halonen, P. I. (1962). Amer. 7. Cardiol., 10, 525.

Pagliaro, L., and Notarbartolo, A. (1962). Lancet, 1, 1043.

Preston, J. A., Batsakis, J. G., and Briere, R. O.'(1964). Amer. F. clin. Path., 41, 237.

Reitman, S., and Frankel, S. (1957). Ibid., 28, 56.

Rosalki, S. B. (1962). F. clin. Path., 15, 566.

(1963). Brit. Heart 7., 25, 795.

Rowell, N. R., and Smith, A. J. (1959). Brit. med. f., 2, 459.

Trethewie, E. R. (1958). Ibid., 2, 1428.

Wilkinson, J. H. (1962). An Introduction to Diagnostic Enzymology. Arnold, London.

Woods, J. D., Laurie, W., and Smith, W. G. (1963). Lancet, 2, 265.

World Health Organization (1959). Tech. Rep. Ser., No. 168.

\title{
Arcus Senilis in Middle-aged Men
}

\author{
G. M. MCANDREW,* M.B., M.R.C.P.ED. ; D. OGSTON,* M.A., M.B., PH.D., M.R.C.P.ED.
}

Brit. med. F., 1965, 1, 425-427

The possibility that an arcus senilis might provide a readily recognized manifestation of the presence of atherosclerosis has intrigued clinicians for many years. Most recent work, however, suggests that the incidence of arcus senilis depends not on the presence of atherosclerosis but on advancing age (Rodstein and Zeman, 1963 ; Lindholm, 1960). Agreement is not yet complete: Pomerantz (1962) found that the incidence of arcus senilis was greater in patients who had sustained a myocardial infarction, while Rodstein and Zeman (1963) noted a significant correlation between the degree of arcus senilis and the incidence of electrocardiographic abnormalities in elderly patients.

We have compared the incidence and degree of arcus senilis in two groups of middle-aged subjects, one group comprising patients who had suffered a myocardial infarction and the second group patients without clinical or electrocardiographic evidence of ischaemic heart disease. We have further studied the group of post-cardiac-infarction patients to determine whether the presence of an arcus senilis in this group is associated with a high serum-cholesterol level, a raised bloodpressure, or a more massive physique.

\section{Methods}

Serum Cholesterol.-This was estimated on a Technicon Autoanalyzer as described by Green et al. (1963).

Body. Build.-Height was measured to the nearest $\frac{1}{4}$ in. $(0.6 \mathrm{~cm}$.). Weight, without shoes and jacket, was measured to the nearest $\frac{1}{4} \mathrm{lb}$. $(0.11 \mathrm{~kg}$.) ; $4 \mathrm{lb}$. (1.8 kg.) was subtracted from this weight to account for the remaining clothing. The

\footnotetext{
* Lecturer in Medicine, University of Aberdoen.
}

ponderal index, a measure of body mass, was estimated according to the formula:

$$
\text { P.I. }=\frac{\text { Height in inches }}{v^{\prime} \text { Weight in } \mathrm{lb} .}
$$

This index has been discussed by Sheldon et al. (1940).

Subjects.-(a) 100 Post-cardiac-infarction Patients. These had been admitted to hospital 3 to 53 months previously, at which time electrocardiographic evidence of cardiac infarction was present. All were receiving therapeutic doses of phenindione, the Quick one-stage prothrombin time being kept between two and a half and three times the control. All were men aged 40 to 69 at the time of this study.

(b) 100 Control Patients. These were male patients aged 40 to 69 admitted to hospital suffering from a variety of medical disorders. All had electrocardiographic tracings free from ischaemic changes and none had a history or clinical evidence of occlusive vascular disease. The number in each age-decade was chosen to match the number in the post-cardiac-infarction decades.

Classification of Arcus Senilis.-Assessment of arcus senilis in all patients was made by the same observer with the aid of artificial light. The following grades were recognized: grade 0 , no observable arcus senilis ; grade 1 , either an upper or a lower arc of opacity in the cornea; grade 2 , a lower and an upper arc of opacity in the cornea; grade 3, a ring of opacity in the cornea, although not prominent, seen to be complete on close scrutiny ; and grade 4, a prominent, complete ring of opacity in the cornea. Grade 4 would be referred to as a marked arcus senilis in clinical practice.

All blood-pressure readings were carried out by a single observer. Blood samples for estimation of serum cholesterol were withdrawn between 2 and 3 p.m. 
Results

\section{Incidence and Grading of Arcus Senilis}

Table I shows that the incidence of arcus senilis in the postcardiac-infarction and control subjects does not differ significantly.

\begin{tabular}{|c|c|c|c|c|}
\hline \multicolumn{5}{|c|}{ Table I } \\
\hline & $\begin{array}{l}\text { Mean } \\
\text { Age }\end{array}$ & $\begin{array}{c}\text { Arcus } \\
\text { Present }\end{array}$ & $\begin{array}{l}\text { Arcus } \\
\text { Absent }\end{array}$ & Total \\
\hline $\begin{array}{l}\text { Post-cardiac infarction subjects.. } \\
\text { Control subjects ... }\end{array}$ & $\begin{array}{l}56 \cdot 4 \\
56 \cdot 0\end{array}$ & $\begin{array}{l}51 \\
44\end{array}$ & $\begin{array}{l}49 \\
56\end{array}$ & $\begin{array}{l}100 \\
100\end{array}$ \\
\hline
\end{tabular}

Table II presents the incidence of arcus senilis in the three age-groups of post-cardiac-infarction and control patients. It is seen that both show a similar rise in the incidence of arcus senilis with advancing age. The difference in incidence between post-cardiac-infarction and control patients in each age-group does not reach the $5 \%$ level of significance.

Table III shows the incidence of the different grades of arcus senilis in the post-cardiac infarction and control patients divided again according to age-group. The incidence of a marked arcus senilis increases with age, but there is little difference between the post-cardiac-infarction and control patients.

\begin{tabular}{|c|c|c|c|c|}
\hline Age-group & $\underset{\text { (years) }}{\text { Mean Age }}$ & $\begin{array}{l}\text { No. of } \\
\text { Subjects }\end{array}$ & $\begin{array}{l}\text { Arcus } \\
\text { Present }\end{array}$ & $\begin{array}{c}\text { Arcus } \\
\text { Absent }\end{array}$ \\
\hline \multicolumn{5}{|c|}{ Post-cardiac-infarction Subjects } \\
\hline $\begin{array}{l}40-49 \\
50-59 \\
60-69\end{array}$ & $\begin{array}{l}44 \cdot 5 \\
55 \cdot 5 \\
63 \cdot 2\end{array}$ & $\begin{array}{l}20 \\
42 \\
38\end{array}$ & $\begin{array}{r}6 \\
21 \\
24\end{array}$ & $\begin{array}{l}14 \\
21 \\
14\end{array}$ \\
\hline \multicolumn{5}{|c|}{ Control Subjects } \\
\hline $\begin{array}{l}40-49 \\
50-59 \\
60-69\end{array}$ & $\begin{array}{l}43 \cdot 9 \\
55 \cdot 0 \\
63 \cdot 2\end{array}$ & $\begin{array}{l}20 \\
42 \\
38\end{array}$ & $\begin{array}{r}5 \\
19 \\
20\end{array}$ & $\begin{array}{l}15 \\
23 \\
18\end{array}$ \\
\hline
\end{tabular}

\begin{tabular}{|c|c|c|c|c|c|}
\hline \multirow{2}{*}{ Age-group } & \multicolumn{5}{|c|}{ Grade of Arcus Senilis } \\
\hline & 0 & 1 & 2 & 3 & 4 \\
\hline \multicolumn{6}{|c|}{ Post-cardiac-infarction Subjects } \\
\hline $\begin{array}{l}40-49 \\
50-59 \\
60-69\end{array}$ & $\begin{array}{l}14 \\
21 \\
14\end{array}$ & $\begin{array}{l}5 \\
8 \\
4\end{array}$ & $\begin{array}{l}0 \\
2 \\
6\end{array}$ & $\begin{array}{l}0 \\
8 \\
7\end{array}$ & $\begin{array}{l}1 \\
3 \\
7\end{array}$ \\
\hline \multicolumn{6}{|c|}{ Control Subjects } \\
\hline $\begin{array}{l}40-49 \\
50-59 \\
60-69\end{array}$ & $\begin{array}{l}15 \\
23 \\
18\end{array}$ & $\begin{array}{l}3 \\
8 \\
4\end{array}$ & $\begin{array}{l}1 \\
5 \\
5\end{array}$ & $\begin{array}{l}1 \\
5 \\
3\end{array}$ & $\begin{array}{l}0 \\
1 \\
8\end{array}$ \\
\hline
\end{tabular}

The results of this part of the study indicate that the incidence of arcus senilis is not significantly increased in patients who have suffered a cardiac infarction. They also reveal a progressive rise with advancing years in the incidence and prominence of arcus senilis.

\section{Post-cardiac-infarction Patients}

Table IV compares the mean serum-cholesterol levels, bodybuild measurements, and blood-pressures in the post-cardiacinfarction patients with and without an arcus senilis. As shown previously the incidence of arcus senilis rises with advancing years and the difference in the mean age between these two groups is statistically significant $(\mathrm{P}<0.02)$. As the other measurements depend partly on age, further analysis of the complete group of 100 post-cardiac-infarction patients was not undertaken.

Thirty-two age-matched pairs were drawn from the "arcuspresent" and "arcus-absent" groups. The mean values of serum-cholesterol level, body-build measurement, and blood- pressure, with the significance of the differences, are presented in Table V. None of these differences reaches the $5 \%$ level of significance.

Six patients (mean age 53 years) had a serum cholesterol of $350 \mathrm{mg} . / 100 \mathrm{ml}$. or over. All six of these post-cardiacinfarction patients had an arcus senilis.

The observations on post-cardiac-infarction patients show that arcus senilis is not associated with variations in physique or blood-pressure. An arcus senilis appears to be very frequent when the serum-cholesterol level is very high, but apart from this there is no clear correlation between arcus senilis and serumcholesterol level.

\begin{tabular}{|c|c|c|c|c|c|c|c|c|c|c|}
\hline \multirow{2}{*}{ 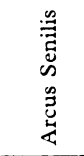 } & \multirow{2}{*}{$\begin{array}{l}0 \\
0 \\
0 \\
\dot{d} \\
. \Xi \\
\dot{0} \\
z\end{array}$} & \multirow{2}{*}{ 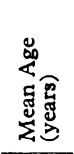 } & \multirow{2}{*}{ 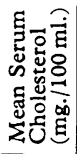 } & \multicolumn{2}{|c|}{$\begin{array}{c}\text { Mean } \\
\text { Height }\end{array}$} & \multicolumn{2}{|c|}{$\begin{array}{c}\text { Mean } \\
\text { Weight }\end{array}$} & \multirow{2}{*}{ 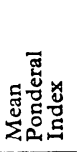 } & \multicolumn{2}{|c|}{$\begin{array}{c}\text { Mean Blood- } \\
\text { pressure } \\
(\mathrm{mm} . \mathrm{Hg})\end{array}$} \\
\hline & & & & in. & $\mathrm{cm}$. & lb. & $\mathrm{Kg}$. & & Syst. & Diast. \\
\hline $\begin{array}{l}\text { Absent } \\
\text { Present }\end{array}$ & $\begin{array}{l}49 \\
51\end{array}$ & $\begin{array}{l}54 \cdot 7 \\
58 \cdot 1\end{array}$ & $\begin{array}{l}260 \\
267\end{array}$ & $\begin{array}{l}66 \cdot 8 \\
66 \cdot 1\end{array}$ & $\begin{array}{l}169 \\
168\end{array}$ & $\begin{array}{l}160 \cdot 0 \\
153.4\end{array}$ & $\begin{array}{l}72 \cdot 6 \\
69 \cdot 6\end{array}$ & $\begin{array}{l}12 \cdot 35 \\
12 \cdot 39\end{array}$ & $\begin{array}{l}130 \cdot 7 \\
141 \cdot 6\end{array}$ & $\begin{array}{l}77 \cdot 9 \\
82.5\end{array}$ \\
\hline \multicolumn{2}{|c|}{ S. of D. (P) } & $<0.02$ & - & 一 & & - & & - & - & - \\
\hline
\end{tabular}

\begin{tabular}{|c|c|c|c|c|c|c|c|c|c|c|}
\hline \multirow{2}{*}{ 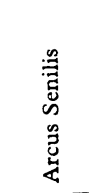 } & \multirow{2}{*}{ 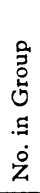 } & \multirow{2}{*}{ 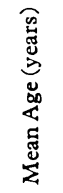 } & \multirow{2}{*}{ 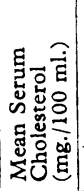 } & \multicolumn{2}{|c|}{$\begin{array}{c}\text { Mean } \\
\text { Height }\end{array}$} & \multicolumn{2}{|c|}{$\begin{array}{c}\text { Mean } \\
\text { Weight }\end{array}$} & \multirow{2}{*}{ 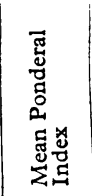 } & \multicolumn{2}{|c|}{$\begin{array}{c}\text { Mean Blood- } \\
\text { pressure } \\
(\mathrm{mm} . \mathrm{Hg})\end{array}$} \\
\hline & & & & in. & $\mathrm{cm}$. & lb. & $\mathrm{Kg}$. & & Syst. & Diast. \\
\hline $\begin{array}{l}\text { Absent } \\
\text { Present }\end{array}$ & $\begin{array}{l}32 \\
32\end{array}$ & $\begin{array}{l}57 \cdot 0 \\
57 \cdot 0\end{array}$ & $\begin{array}{l}254 \\
269\end{array}$ & $\begin{array}{l}66 \cdot 7 \\
65 \cdot 7\end{array}$ & $\begin{array}{l}169 \\
167\end{array}$ & $\begin{array}{l}158 \cdot 2 \\
149 \cdot 4\end{array}$ & $\begin{array}{l}71 \cdot 8 \\
67 \cdot 8\end{array}$ & $\begin{array}{l}12 \cdot 37 \\
12 \cdot 39\end{array}$ & $\begin{array}{l}135 \cdot 0 \\
136.6 \\
\end{array}$ & $\begin{array}{l}78.9 \\
80.6\end{array}$ \\
\hline \multicolumn{2}{|l|}{ S. of D. } & & $\begin{array}{l}0.3> \\
P>0.2\end{array}$ & \multicolumn{2}{|c|}{$\begin{array}{c}0.3>P \\
>0.2\end{array}$} & \multicolumn{2}{|c|}{$\begin{array}{l}0.1>P \\
>0.05\end{array}$} & $\begin{array}{c}0.9>\mathbf{P} \\
>0.8\end{array}$ & $\begin{array}{c}0.7>P \\
>0.6\end{array}$ & $\begin{array}{r}0.7>P \\
>0.6\end{array}$ \\
\hline
\end{tabular}

\section{Discussion}

Arcus senilis, an opacity of the peripheral cornea, is due to the deposition of cholesterol, phospholipids, and neutral fat in the surface membranes and stroma of the cornea (Cogan and Kuwabara, 1959). These workers have also shown that the development of an arcus senilis is not dependent on a degenerative change in the cornea. The fat content of an arcus senilis appears to be derived from the blood, suggesting an analogy with atherosclerosis. It has therefore been popularly supposed that the occurrence of an arcus senilis might be associated with the presence of atherosclerosis.

This study has shown that the incidence of arcus senilis in male patients aged 40 to 69 who have suffered a myocardial infarction does not differ significantly from control patients in the same age range. This is in agreement with the findings of Lindholm (1960). Pomerantz (1962), however, noted that an arcus senilis was more common in post-cardiac-infarction patients aged 35 to 55 than in a control group, but that the incidence did not differ significantly for subjects aged 56 to 60 . In keeping with all previous investigators (Lindholm, 1960 ; Pomerantz, 1962 ; Rodstein and Zeman, 1963) we have found that there is a progressive rise in the incidence of arcus senilis with advancing years.

It has been shown that even a moderate degree of hypertension is associated with an increased rate of development of atherosclerosis (Kannel et al., 1961). It was our intention to determine whether the development of arcus senilis was also influenced by hypertension, but we were unable to demonstrate any such influence.

Gertler and White (1954) found that their group of young subjects with coronary heart disease had a significantly lower ponderal index than the control group. Our study was designed to test whether a body build characterized by a low ponderal 
Index was associated with an unduly high incidence of arcus senilis. Again no such association was shown.

In common with other workers (Lindholm, 1960 ; Rodstein and Zeman, 1963) we have failed to show any close correlation between the presence of an arcus senilis and serum-cholesterol levels. However, all the subjects with a serum-cholesterol level of over $350 \mathrm{mg}$. $/ 100 \mathrm{ml}$. were noted to have an arcus senilis. It would seem that a substantially elevated serum-cholesterol level contributes to the development of an arcus senilis, but that hypercholesterolaemia is not necessary for its development.

The main conclusion from this study must be that the presence or absence of an arcus senilis in middle-aged men gives no useful clinical guide to the presence of atherosclerosis.

\section{Summary}

A comparison of the incidence of arcus senilis was made between middle-aged male post-cardiac-infarction patients and age-matched male patients without clinical or electrocardiographic evidence of occlusive vascular disease. No statistically significant difference in incidence was found. In agreement with previously published observations there was a progressive rise in incidence with advancing age.
Post-cardiac-infection patients with an arcus senilis did not differ from those without an arcus in respect of serum cholesterol, blood-pressure, or body build, except that all patients with a serum cholesterol of over $350 \mathrm{mg} . / 100 \mathrm{ml}$. had an arcus senilis.

We are grateful to Dr. K. G. Green for permission to use the results of serum cholesterol estimations carried out by the Pharmaceuticals Division of Imperial Chemical Industries Ltd. We wish to thank the physicians of Aberdeen General Hospitals for access to patients under their care, and Professor $\mathrm{H}$. W. Fullerton for help and advice in the preparation of this paper.

\section{REFERENCES}

Cogan, D. G., and Kuwabara, T. (1959). Arch. Ophthal., 61, 553. Gertler, M. M., and White, P. D. (1954). Coronary Heart Disease in Young Adults. Oxford Univ. Press, London.

Green, K. G., Inman, W. H. W., and Thorp, J. M. (1963). F. Atheroscler. Res., 3, 593.

Kannel, W. B., Dawber, T. R., Kagan, A., Revotskie, N., and Stokes, J. (1961). Ann. intern. Med., 54, 1035.

Lindholm, H. (1960). Acta med. scand., 168, 45

Pomerantz, H. Z. (1962). Canad. med. Ass. f., 86, 57.

Rodstein, M., and Zeman, F. D. (1963). Amer. F. med. Sci., 245, 70.

Sheldon, W. H., Stevens, S. S., and Tucker, W. B. (1940). The Varieties of Human Physique. Harper, New York.

\title{
Intestinal Absorption of ${ }^{45} \mathrm{Ca}$ in Stone-forming Patients
}

\author{
A. CANIGGIA,*† м.D.; C. GENNARI,* M.D. ; L. CESARI,* м.D.
}

Brit. med. 7., 1965, 1, 427-429

With the use of the calcium-balance method an increased absorption of calcium by the intestine has been demonstrated in primary hyperparathyroidism (Albright, Bauer, Claflin, and Cockrill, 1932 ; Aub, Tibbetts, and McLean, 1937 ; Lichtwitz and Parlier, 1959 ; Lafferty and Pearson, 1963), in hypercalcaemia of sarcoidosis (Anderson, Dent, Harper, and Philpot, 1954 ; Henneman, Dempsey, Carroll, and Albright, 1956), and in idiopathic hypercalcaemia of children (Morgan, Mitchell, Stowers, and Thompson, 1956 ; Stapleton, Macdonald, and Lightwood, 1956). Lichtwitz, de Sèze, Hioco, Miravet, Lanham, and Parlier (1963) were of the opinion that excessive absorption of calcium by the intestine might be the cause of hypercalcaemia in patients with nephrolithiasis. Investigations carried out with the aid of ${ }^{15} \mathrm{Ca}$ and ${ }^{47} \mathrm{Ca}$ have confirmed that in primary hyperparathyroidism intestinal hyperabsorption of calcium is indeed present, and that this disappears after the removal of the parathyroid adenoma (Lichtwitz and Parlier, 1959 ; Jaworski, Brown, Fedoruk, and Seitz, 1963).

We have made a study of the intestinal absorption of ${ }^{45} \mathrm{Ca}$ in six stone-forming patients, including one patient with a large parathyroid adenoma and von Recklinghausen's disease of bone; we have used the same method as that employed earlier for the study of the intestinal absorption of ${ }^{45} \mathrm{Ca}$ in senile osteoporosis (Caniggia, Gennari, Bianchi, and Guideri, 1963).

\section{Clinical Material and Methods}

All the patients studied had multiple renal calculi, while one individual suffered from bilateral nephrocalcinosis. With the exception of the case of primary hyperparathyroidism with bone disease, none of these patients showed alteration of the bones

\footnotetext{
- From the Institute of Medical Semeiology, University of Siena, Siena,

† Professor of Gerontology and Geriatrics in the University of Siena.
}

demonstrable by radiological examination. The renal function was normal in all cases.

The plasma calcium level was high in all but one of the patients (normal range in our laboratory, 9-11 $\mathrm{mg} . / 100 \mathrm{ml}$.) ; the inorganic phosphorus level of the plasma was normal in all cases with the exception of the case of primary hyperparathyroidism (normal range in our laboratory, $2.5-4.5 \mathrm{mg} . / 100$ $\mathrm{ml}$.) ; and the urine level of calcium was high in all cases (normal range in our laboratory, $100-180 \mathrm{mg} . / 24 \mathrm{hr}$.). Alkaline phosphatase was very high in the case of parathyroid adenoma, and normal or borderline in the other cases (normal range in our laboratory, 5-15 K.A. units) (Table I).

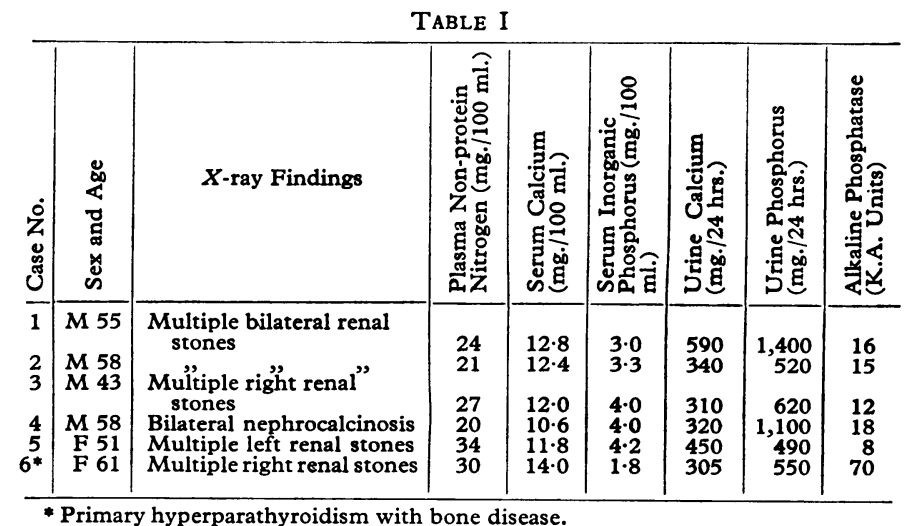

The fasting patients were given $50 \mu \mathrm{c}$ of ${ }^{45} \mathrm{CaCl}_{2}$ (containing $5 \mathrm{mg}$. of calcium as carrier) orally at 8 a.m., dissolved in $10 \mathrm{ml}$. of a $10 \%$ calcium gluconate solution (containing $88 \mathrm{mg}$. of calcium as additional carrier).

Samples of venous blood were taken every five minutes for a period of 30 minutes, then every 10 minutes during the next 